\title{
Absence of Epstein-Barr virus RNA in multiple sclerosis as assessed by in situ hybridisation
}

\author{
David A Hilton, Seth Love, Alan Fletcher, James H Pringle
}

\begin{abstract}
Epidemiological and serological evidence has suggested a role for Epstein-Barr virus infection in the aetiology of multiple sclerosis. Epstein-Barr virus-specific RNA was looked for in the brains of 10 patients with multiple sclerosis by in situ hybridisation. A total of 21 plaques was examined. In all of these preservation of RNA was shown by hybridisation of control probes to mitochondrial rRNA but no signal was detected with the EpsteinBarr virus probes. It is unlikely that persistent or latent Epstein-Barr virus infection of the CNS occurs in multiple sclerosis, although present findings do not exclude a role for Epstein-Barr virus in the initiation of this disorder.
\end{abstract}

(Ұ Neurol Neurosurg Psychiatry 1994;57:975-976)

There is considerable epidemiological evidence to suggest that an infectious agent may cause or, at least, precipitate multiple sclerosis. ${ }^{1}$ Some studies have implicated EpsteinBarr virus ${ }^{2-7} ; 99-100 \%$ of patients with multiple sclerosis are seropositive for EBV. ${ }^{23}$ Eighty five per cent of patients with multiple sclerosis but only $13 \%$ of Epstein-Barr virus seropositive controls have CSF antibodies to Epstein-Barr virus nuclear antigen. ${ }^{4}$ Of five patients with primary Epstein-Barr virus infection complicated by CNS involvement, four developed classical multiple sclerosis and one a diffuse demyelinating disorder. ${ }^{5}$ It has also been shown that patients with infectious mononucleosis have an increased risk of developing multiple sclerosis, ${ }^{6}$ particularly if infection occurred before the age of 18 years. ${ }^{7}$

We have looked for Epstein-Barr virus in the brains of cases of multiple sclerosis by in situ hybridisation with oligonucleotide probes to Epstein-Barr virus RNAs that are highly expressed in both replicative and latent infection. ${ }^{8}$

\section{Methods}

PROBES

Synthetic oligonucleotides complementary to the highly expressed EBER 1 and 2 nuclear RNAs $^{8}$ were synthesised on a DNA synthesiser (model 380b, Applied Biosystems, Warrington, UK) and labelled at the $3^{\prime}$ end using terminal deoxynucleotidyl transferase with a homopolymer tail of dUTP-11-digoxigenin (Boehringer Mannheim).

Probes to mitochondrial $\mathrm{rRNA}^{9}$ were used to assess preservation of RNA in the tissue sections.

\section{CASES}

Ten cases of multiple sclerosis were selected that had, at necropsy, been subjected to detailed neuropathological examination in the Department of Neuropathology, Frenchay Hospital. Duration of disease had varied from six months to 27 years and the ages at death ranged from 46 to 71 years. Sections of cerebral hemisphere and, in one of the cases brainstem, were used for in situ hybridisation. These included a total of 21 plaques, of which four were from cases of acute multiple sclerosis, 11 were chronic active plaques, two were chronic inactive, and four were shadow plaques (according to the classification of Raine $^{10}$ ).

Sections of a lymph node from a case of Hodgkin's disease were used as positive controls for the EBER probes.

\section{IN SITU HYBRIDISATION}

Paraffin sections, $4 \mu \mathrm{m}$ in thickness, were collected on to aminopropyltriethoxysilanecoated glass slides. The sections were dewaxed in xylene and graded alcohols, washed in $2 \times \mathrm{SSC}$ at $70^{\circ} \mathrm{C}$ for 10 minutes, treated with $15 \mu \mathrm{g} / \mathrm{ml}$ proteinase $\mathrm{K}$ for 60 minutes at $37^{\circ} \mathrm{C}$, and refixed in $0.4 \%$ paraformaldehyde in $0 \cdot 1 \mathrm{M}$ phosphate buffer for 20 minutes at $4^{\circ} \mathrm{C}$. Hybridisation was overnight at $37^{\circ} \mathrm{C}$ in $50 \mu \mathrm{l}$ of buffer containing $0.1 \mathrm{ng} / \mu \mathrm{l}$ probe, $30 \%$ formamide, 600 $\mathrm{mM} \mathrm{NaCl}, 0.1 \mathrm{M}$ phosphate buffer, $10 \%$ dextran sulphate, and $150 \mu \mathrm{g} / \mathrm{ml}$ sheared salmon sperm DNA. Posthybridisation washes were in $2 \times$ SSC and $30 \%$ formamide at $37^{\circ} \mathrm{C}$. Sections were blocked for $10 \mathrm{~min}-$ utes in Tris $\mathrm{HCl}(\mathrm{pH} 7.5), 0.5 \mathrm{M} \mathrm{NaCl}, 3 \%$ bovine serum albumin, then incubated for 30 minutes with digoxigenin antibody (diluted 1:600) conjugated to alkaline phosphatase. The colour reaction was performed with nitroblue tetrazolium salt and 5-bromo-4chloro-3-indoyl phosphate solution in the dark for up to 22 hours. 
Sections through the edge of an active plaque from $a$ case of acute multiple sclerosis.

(A) Numerous

lymphocytes and macrophages are present within the plaque (towards left of figure) and along the border with adjacent white matter. Luxol fast blue/cresyl violet; Bar $=$ $100 \mu \mathrm{m}$

(B) Mitochondrial $r R N A$ is readily demonstrable within inflammatory cells and astrocytes by in situ hybridisation.

(C) No hybridisation signal is detected with probes to EBV RNA.
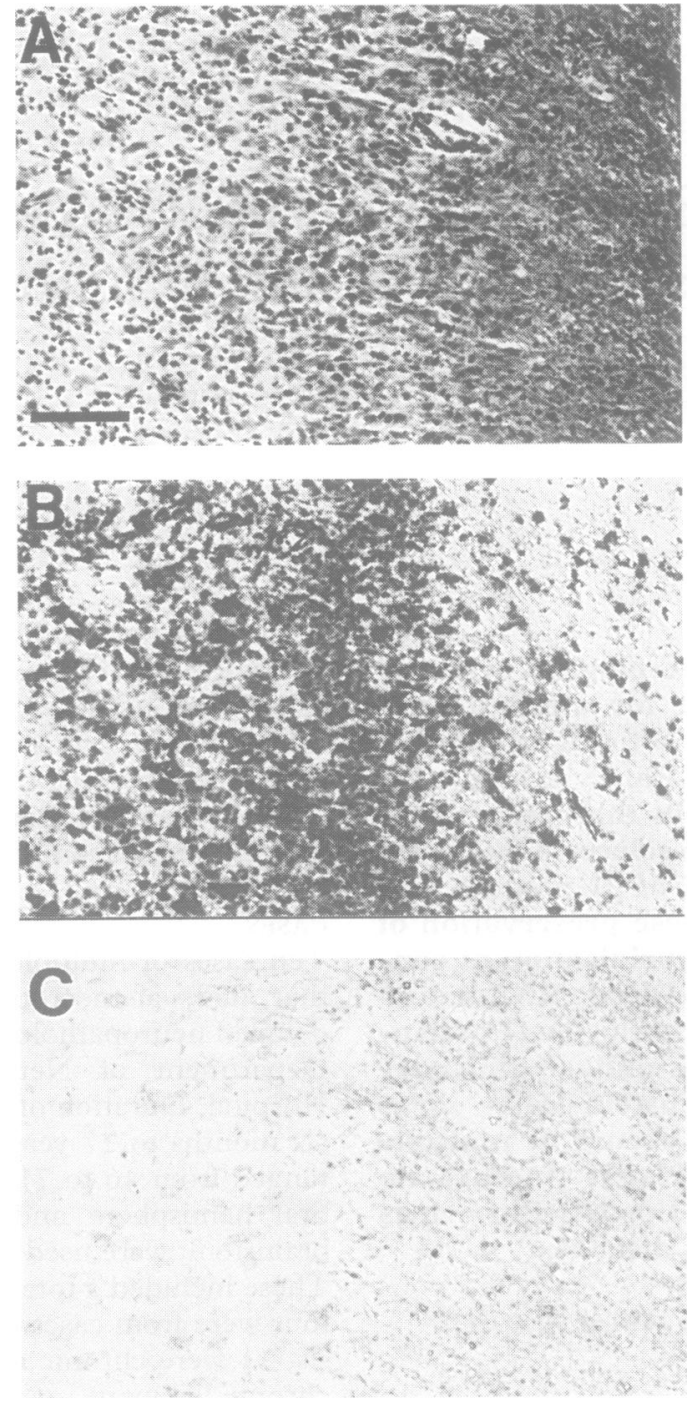

Results

Preservation of RNA was shown with the mitochondrial rRNA probes in all cases, in both grey and white matter, although in one case preservation was limited to the edge of the tissue section (presumably the region most rapidly penetrated by formalin). Hybridisation to mitochondrial rRNA was noted in cortical neurons, oligodendrocytes, endothelial cells, and in the cytoplasm of perivascular lymphocytes within plaques (figure). In none of the cases of multiple sclerosis was there detectable Epstein-Barr virus RNA with the EBER probes (figure). The lymph node control sections showed a strong signal within scattered Reed-Sternberg nuclei with the same probes.

\section{Discussion}

The probes used for in situ hybridisation in this study are directed against the very highly expressed EBER RNA molecule $\left(10^{7}\right.$ copies/cell), which is expressed in both lytic and latent infection. ${ }^{8}$ With these probes we have previously detected Epstein-Barr virus RNA in tissues sections from cases of infectious mononucleosis, lymphoma, oral hairy leucoplakia and nasopharyngeal carcinoma. ${ }^{11}$

The use of the polymerase chain reaction would represent a sensitive alternative method for the detection of small quantities of viral nucleic acid in paraffin sections. ${ }^{9}$ Positive findings would be difficult to interpret, however, because of possible amplification of Epstein-Barr virus from latently infected lymphocytes, ${ }^{12}$ particularly in the light of the high Epstein-Barr virus seropositivity rate in multiple sclerosis. ${ }^{23}$

The evidence associating Epstein-Barr virus with multiple sclerosis has been based largely on immunological data but the finding of increased viral antibody titres in cases of multiple sclerosis is not confined to EpsteinBarr virus. Raised antibody titres to measles and mumps ${ }^{13}$ and a number of other viruses are reported in patients with multiple sclerosis and similar increases in viral antibody titres to those in multiple sclerosis have been documented in patients with rheumatoid arthritis, ${ }^{13}$ which has a well recognised autoimmune basis. The serological findings in multiple sclerosis may therefore reflect non-specific immunological activation. The absence of demonstrable Epstein-Barr virus RNA by in situ hybridisation in brain tissues from any of the 10 cases of multiple sclerosis in the present study indicates that persistent or latent Epstein-Barr virus infection of the CNS is unlikely in these patients. The findings do not, however, exclude a role for Epstein-Barr virus in the initiation of multiple sclerosis.

1 Martyn CN. In: Matthews WB, ed. McAlpine's multiple sclerosis. 2nd ed. Edinburgh: Churchill Livingstone, 1991.

2 Sumaya CV, Myers LW, Ellison GW. Epstein-Barr virus antibodies in multiple sclerosis. Arch Neurol 1980;37: 94-6.

3 Larsen PD, Bloomer LC, Bray PF. Epstein-Barr nuclear antigen and virus capsid antigen titres in multiple sclerosis. Neurology 1985;35:435-8

sis. Neurology 1985;35:435-8.
4 Bray PF, Luka J, Culp KW, Schlight JP. Antibodies against Epstein-Barr nuclear antigen (EBNA) in multiagainst Epstein-Barr nuclear antigen (EBNA) in multiple sclerosis CSF, and two pentapeptide sequence ident--
ties between EBNA and myelin basic protein. Neurology ties between EBNA

5 Bray PF, Culp KW, Mcfarlin DE, Panitch HS, Torkelson $\mathrm{RD}$, Schlight JP. Demyelinating disease after neurologically complicated primary Epstein-Barr virus infection. Neurology 1992;42:278-82.

6 Lindberg C, Anderson O, Vahlne A, Dalton M, Runmarker B. Epidemiological investigation of the association between infectious mononucleosis and multiple sclerosis. Neuroepidemiology 1991;10:62-5.

7 Martyn CN, Cruddas M, Compston DAS. Symptomatic Epstein-Barr virus infection and multiple sclerosis. I Neurol Neurosurg Psychiatry 1993;56:167-8.

8 Glickman JN, Howe JG, Steitz JA. Structural analyses of EBER1 and EBER2 ribonucleoprotein particles present in Epstein-Barr virus infected cells. $\mathcal{F}$ Virol 1988;62:902in Eps.

9 Hilton DA, Variend S, Pringle JH. Demonstration of coxsackie virus RNA in formalin-fixed tissue sections from sackie virus RNA in formalin-fixed tissue sections from
cases of childhood myocarditis cases by in situ hybridisacases of childhood myocarditis cases by in situ hybridisa-
tion and the polymerase chain reaction. $\mathcal{f}$ Pathol tion and the poly

10 Raine CS. Demyelinating diseases. In: Davis RL, Robertson DM, eds, Textbook of neuropathology. 2nd ed. Baltimore, MD: Williams and Wilkins, 1991.

11 Pringle JH, Barker S, Warford A, Lauder I. Demonstration of Epstein-Barr virus in tissue sections by in situ hybridisation for viral RNA. F Pathol 1992;167:(suppl): 133A.

12 Brocksmith D, Angel CA, Pringle JH, Lauder I. EpsteinBarr viral DNA in Hodgkin's disease: amplification and detection using the polymerase chain reaction. $f$ Pathol 1991;165:11-15.

13 Shirodaria PV, Haire M, Fleming E, Merrett JD, Hawkins SA, Roberts SD. Viral antibody titres. Comparison in patients with multiple sclerosis and rheumatoid arthritis. Arch Neurol 1987;44:1237-41. 